\title{
X-RAY STRUCTURE ANALYSES OF AIR HYDRATES IN A DEEP ICE CORE FROM DYE 3, GREENLAND \\ (Abstract)
}

\author{
by
}

T. Hondoh, H. Anzai, N. Hayakawa*, S. Mae, A. Higashi**

(Department of Applied Physics, Faculty of Engineering, Hokkaido University, Sapporo 060, Japan)

and

C.C. Langway, $\mathrm{Jr}$

(Department of Geological Sciences, State University of New York at Buffalo, 4240 Ridge Lea Road, Amherst, NY 14226, U.S.A.)

\begin{abstract}
Clathrate hydrate inclusions of various shapes and sizes were first found by Shoji and Langway (1982) in ice cores from a depth greater than $1280 \mathrm{~m}$ at Dye 3, Greenland. Although we have assigned clathrate guest molecules to $\mathrm{O}_{2}$ and $\mathrm{N}_{2}$ by observing Raman spectra of the hydrates in a core from $1501 \mathrm{~m}$ depth (Nakahara and others, in press), it has not been determined whether the crystal structure of the hydrate is structure I or structure II.

Using the 4-circle diffractometer in the High Brilliance $\mathrm{X}$-ray Laboratory at Hokkaido University, many reflections from the hydrate crystals were identified. Applying extinction rules for cubic crystals, the space group of the hydrate was determined as $\mathrm{Fd} 3 \mathrm{~m}$, which corresponded to structure II. The average lattice parameter for a unit cell obtained from three samples was $17.21 \AA$, and this also supports structure II. Structure II was also found with artificial air hydrates by the method of neutron diffraction (Davidson and others 1984).

The density of the hydrate was calculated for various combinations of the occupancy of the two types of cage by
\end{abstract}

guest molecules (in a composition ratio of $\mathrm{N}_{2}: \mathrm{O}_{2}=(1.5$ 2.0): 1 as determined from Raman intensity). A reasonable value of the density $950 \mathrm{~kg} \mathrm{~m}^{-3}$ was obtained when only the 12-hedrons were occupied. Therefore it was concluded that the air molecules were trapped only in 12-hedrons which formed the structure II hydrate with 16-hedrons.

\section{REFERENCES}

Davidson D W, Gough S R, Handa Y P, Ratcliffe C I, Ripmeester J A, Tse, J S 1987 Some structural studies of clathrate hydrates. Journal de Physique 48(C1): 537-542

Nakahara J, Shigesato $Y$, Higashi A, Hondoh $T$ In press. Raman spectra of natural clathrate in deep ice core. Philosophical Magazine

Shoji H, Langway C C Jr 1982 Air hydrate inclusions in fresh ice core. Nature 298(5874): 548-550

Present address: ${ }^{*}$ Canon Co. Ltd, Tokyo **International Christian University, Tokyo 